\title{
Titofania. \\ Formy obecności symbolicznej Josipa Broza Tity w Jugosławii doby socjalizmu ${ }^{1}$
}

\begin{abstract}
Bogusławska Magdalena, „Titofania”. Formy obecności symbolicznej Josipa Broza Tity w Jugostawii doby socjalizmu (,Titophany”. Forms of Symbolic Presence of Josip Broz Tito in the Socialist Yugoslavia). „Poznańskie Studia Slawistyczne” 5. Poznań 2013. Adam Mickiewicz University Press, pp. 45-58. ISBN 978-83-232-2636-9. ISSN 2084-3011.

Text is an analysis of symbolic strategies, serving creation of Josip Broz Tito's authority as the leader of the socialist Yugoslavia; it also reveals their cultural and political motivations. Author indicates three dominant factors in the process of cult creation, which are characteristic for the cult of personality in totalitarian systems; as such they also remain a specific continuation of traditions as a base of the local power culture. In this perspective, the Tito's cult and political mythology as its frame is an endemic embodiment of mythological provincionalism with universal aspirations - typical for communism. The function of this cult is a consolidation of multi-nation community and legitimization of federal state formula in the conditions of immaturity of the local political culture.
\end{abstract}

Keywords: Josip Broz Tito; Yugoslavia; communism; propaganda; cult of personality; heroization; sacralization; deification; religious anthropomorfization

W podporządkowanym dyrektywom komunistycznej elity partyjnej procesie tworzenia i instytucjonalizacji kultu Josipa Broza oraz wspierajacej ów kult mitologii, możemy wyróżnić trzy zasadnicze odsłony ewolucji publicznego wizerunku Tity jako lidera partii komunistycznej, a przede wszystkim przywódcy państwa. Każda z nich krystalizuje się na określonym etapie jego politycznej i osobistej biografii, a zarazem niesie ze sobą

\footnotetext{
${ }^{1}$ Tekst został przygotowany w ramach projektu badawczego nr 2012/05/B/HS2/04097 pt. Josip Broz Tito. Od spektaklu władzy do teatru pamięci, finansowanego ze środków Narodowego Centrum Nauki.
} 
odrębną od pozostałych treść, nota bene silnie osadzoną w pewnych schematach i mechanizmach wyobrażeniowych, dzięki którym każde z „,wcieleń" Tity zostaje wyposażone w określoną perswazyjną moc, implikuje charakterystyczną postawę percepcyjną i służy uruchomieniu pożądanej reakcji emocjonalnej. Ewolucja wizerunku przywódcy socjalistycznej Jugosławii, w interesującej tu odmianie apologetycznej, nie tylko nie wyklucza zatem współistnienia kolejnych odsłon, lecz także wydaje się, że dyskurs propagandowy wręcz zakłada i wykorzystuje ich koegzystencję oraz nakładanie się na siebie ${ }^{2}$. Reprezentują one pewne konstrukcje symboliczne, które w niniejszym tekście chciałabym opisać poprzez wyróżnienie porządkujących ich znaczenia dominant - takich jak heroizacja, deifikacja i antropomorfizacja ubóstwionego przywódcy, ponieważ wspólnym mianownikiem jest religijny, sakralizujący stosunek do władzy. Stanowią one podstawę określonych strategii wizerunkowych i jako takie odzwierciedlają dynamikę przemian społecznego funkcjonowania obrazu Marszałka, prowadzącą od narodzin mitu, poprzez jego instytucjonalizację do inkorporacji w obszar świadomości i wyobraźni potocznej.

W okresie drugiej wojny światowej Josip Broz zaczyna być ukazywany jako charyzmatyczny lider partii komunistycznej, ale przede wszystkim waleczny Komendant oddziałów partyzanckich, zwycięski przywódca rewolucji. Temu etapowi wizerunkowych narracji odpowiada kult wojownika bohatera, wzmacniany posłuchem i entuzjazmem rosnącymi w szeregach działaczy partii i przybierającymi swoiste formy adoracji. Kształtująca się $w$ warunkach wojennych legenda znajduje wyraz $w$ anonimowej twórczości partyzanckiej mocno osadzonej w poetyce ludowej, wpisanej w socrealistyczne schematy (Kornhauser 2001). Dobrą ilustracją zabiegów wizerunkowych, które budują podstawy sakralnego oddziaływania postaci Tity w roli dowódcy, jest m.in. utrzymany w konwencji tradycyjnej pieśni epickiej poemat Vladimira Nazora Titov „Naprijed!”. W utworze tym jadący konno na czele partyzanckiej kolumny Tito napotyka na drodze demoniczne personifikacje lęku, głodu, zwątpienia, próbujące odwieść go od powziętych decyzji i zawrócić z drogi. Zarówno sama postać, jak i spo-

\footnotetext{
${ }^{2} \mathrm{~W}$ procesie formowania publicznego wizerunku Josipa Broza możemy wyróżnić także wcześniejsze fazy, jak choćby tę związaną z działalnością rewolucyjną, partyjną i agenturalną w latach międzywojnia, kiedy jego udziałem staje się m.in. rola trybuna robotników, przypisywana mu przez oficjalnych biografów (Николић 2006: 21-32).
} 
sób poetyckiego obrazowania, przywodzą na myśl utrwaloną w pieśniach gęślarskich sylwetkę Królewicza Marka i innych południowosłowiańskich bohaterów - junaków, rycerzy. Fantastyczny entourage, w jakim ukazywany jest Tito, oparty na transpozycji motywów ludowych, stanowi przejaw skłonności twórczej wyobraźni do tego, co cudowne, osobliwe, dziwne, a co podsyca myślenie mityczne i uruchamia wyobraźnię metafizyczną. Stąd też wojennej heroizacji osoby Josipa Broza, za sprawą której zostaje on wyposażony $\mathrm{w}$ nadnaturalne moce i nadludzkie atrybuty, towarzyszy sakralizacja. Jej przejawem jest m.in. zastosowanie w panegirycznych utworach dedykowanych Marszałkowi charakterystycznej topiki mistycznej. W wierszu kosowskiego poety Adema Gajtaniego jest to element światła: On [Tito] se javlja iz svetlosti / I u svetlost se pretvara (Ćalović 2006: 277). Ta plastyczna metafora, przypominająca sposób przedstawiania świętych na ikonach ${ }^{3}$, wskazuje na cudowny rodowód Tity jako bohatera kulturowego oraz na metafizyczny $w$ istocie rzeczy sens jego działania.

Serbski historyk Kosta Nikolić w pracy Tito govori što narod misli, poświęconej wczesnej, powojennej fazie kultu Josipa Broza, obecność i trwałość elementu mistycznego w wyobrażeniach o Ticie tłumaczy specyfiką serbskiej religijności oraz niedostatkiem wyrazistego bóstwa, umocowanego w okrzepłej instytucjonalnie myśli teologicznej, „brakiem prawdziwej religii”, która w latach powojennych mogłaby stanowić realną alternatywę dla parareligii czy też religii społecznej, jaką stał się titoizm (Николић 2006). Pomijając oczywiste kontrowersje wynikające z partykularyzacji jugosłowiańskiego doświadczenia komunizmu, która w omawianym wypadku polega na wskazaniu motywacji kulturowej zjawiska z perspektywy tylko jednego podmiotu narodowego (Serbowie), należy zauważyć, że teza Nikolicia opiera się na uproszczonej interpretacji etnologicznych koncepcji na temat serbskiej religijności (bez zaznaczenia, na ile można ją odnieść do innych wspólnot narodowych i wyznaniowych tworzących Jugosławie). Badacz ujmuje problem przez pryzmat braku, choć zdecydowanie bardziej płodne byłoby tu rozpatrzenie kultu Tity w jego pogańskich i chrześcijańskich uwikłaniach, w odniesieniu do kate-

\footnotetext{
${ }^{3}$ Malarski efekt światła osiągany np. poprzez użycie złotej barwy nadaje ikonie status hierofanii.
} 
gorii synkretyzmu religijnego (zwłaszcza do zjawiska ludowego panteizmu), tym bardziej że tak właśnie system wierzeniowy Serbów proponują ujmować Veselin Čajkanović oraz współczesny przedstawiciel badań (serbskiego) ludowego prawosławia Dušan Bandić, a do tego rodzaju etnologiczno-religioznawczych rozstrzygnięć Nikolić pośrednio nawiązuje.

Relacja między jugosłowiańskim komunizmem a religią - w jej instytucjonalnych i pozainstytucjonalnych, ludowych, potocznych odmianach, a także konfesyjnym zróżnicowaniu - jest kwestią złożoną, wymagającą rozbudowanych i pogłębionych studiów. Dla niniejszych rozważań istotne są zasadniczo dwa założenia.

Po pierwsze, analizując kult Josipa Broza Tity, warto pamiętać, że ideologia komunistyczna w Jugosławii stanowiła fundament i rację istnienia federacji i jako taka miała odgrywać rolę systemu jednoczącego narody i grupy współtworzące nowe państwo. W tym kontekście można zabiegi deifikacji Tity, a zwłaszcza ich konsekwencje dla „ludowej” percepcji uwznioślonego przez propagandę wizerunku, odczytywać jako odpowiednik osadzonej w przedchrześcijańskich pokładach kultury ludowej tradycji „bóstwa naczelnego” (serb. vrhovni bog). Ponieważ praktycznym przeznaczeniem tej kreacji była właśnie konsolidacja heterogenicznej wspólnoty Jugosłowian, musiała ona pomagać w przewartościowaniu głębokich podziałów, w tym także wyznaniowych, stanowiących w historii regionu zasadniczy czynnik różnicujący, a w konsekwencji także konfliktogenny. Formowaniu się podmiotowości jugosłowiańskiej towarzyszyły wszakże emancypacyjne dążenia poszczególnych grup narodowych, z perspektywy których federacyjna formuła państwa wydawać się mogła niezadowalającym w pełni, tymczasowym kompromisem. Architekci jugosocjalistycznej wspólnoty zdawali sobie sprawę, że należy zorganizować ją, zgodnie $\mathrm{z}$ tradycyjnym rytuałem kosmogonicznym, wokół wyodrębnionego centrum, stałego, niezmiennego, absolutnego punktu, o mocnym aksjologicznym podłożu i wyrazistej strukturze symbolicznej. Tym centrum stał się kult Josipa Broza Tity. Początkowo „wyznawany” w kręgach partyjnych oraz propagowany w szeregach partyzanckich, stopniowo i konsekwentnie przeobrażał się w kult ogólnopaństwowy, a mieszkańcy Jugosławii - jak ma to miejsce w poetyckiej wizji Oskara Davičo, pochodzącej z pochwalnego utworu Tito ne može da umre - w „Titosłowian” (Andrić, Ršumović (red.) 1981: 238). 
Drugie zastrzeżenie ma charakter ogólny. Dla antropologicznie zorientowanych badań nad fenomenem sakralizacji jugosłowiańskiego przywódcy istotne wydaje się zasygnalizowanie kwestii związanych z użyciem podstawowych pojęć i ze sposobami rozumienia reprezentujących je zjawisk, przy świadomości jednak, że kwestie te wpisują się w rozległy kompleks zagadnień teoretycznych i dyskusji o charakterze religioznawczym, na referowanie których nie ma tu niestety miejsca. Otóż, rozważając zagadnienie kultu Josipa Broza i sakralizacji władzy w socjalistycznej Jugosławii, można uznać komunizm za religię, do czego zresztą upoważniać by mogła szeroka definicja tego zjawiska, wyrastająca z koncepcji Jeana-Jacques'a Rousseau i Emila Durkheima, a formułowana przez takich socjologów religii, jak na przykład Thomas Luckmann, który dostrzega religię w każdym systemie służącym konsolidacji i legitymizacji ładu społecznego, niezależnie od tego, czy system ten zakłada istnienie sfery nadprzyrodzonej, czy nie, ta bowiem stanowi, podobnie jak subiektywne treści doświadczenia religijnego, wymiar z perspektywy socjologicznej nieweryfikowalny empirycznie (Luckmann 2006).

Niniejsza analiza dotyczy jednak nie tylko uniwersalnych mechanizmów uznawanych za charakterystyczne dla funkcjonalistycznie pojmowanych instytucji społecznych, identyfikowanych jako religijne, lecz także obejmuje zależności pomiędzy ukształtowaną historycznie tradycją religijną a narzuconym odgórnie systemem politycznym, jak i oddziaływanie tych związków na specyfikę kultury władzy (reprezentującej dziedzinę kultury politycznej) interesującego mnie obszaru geograficznego. Stąd też znacznie bardziej inspirujące w opisie dynamiki tej, kluczowej dla rozważań, relacji pomiędzy zjawiskami religijnymi a określoną ideologią i praktyką polityczna, wydaje się optyka zaproponowana przez Marcina Kulę. Przywołuje on mianowicie konotacje uruchamiane przez złożenie religiopodobny (derywowany analogicznie do peerelowskich neologizmów w rodzaju wyrób czekoladopodobny) i za pomocą tego określenia opisuje komunizm jako system, który, mimo deklarowanej wrogości wobec religii i Kościoła, wykorzystuje - mniej lub bardziej otwarcie - zarówno konkretne doświadczenia bądź tradycje wyznaniowe kultury, w której funkcjonuje, jak i sprawdzone mechanizmy oraz formy władzy symbolicznej, mające proweniencję religijną. Ukształtowana w łonie jugosłowiańskiego komunizmu kultura władzy będzie się zatem odwoływać do specyficznych dla 
danej kultury form sakralizacji osoby panującego jako jednej z rudymentarnych, a także sprawdzonych strategii jej legitymizowania. Zakorzenienie w głębokich pokładach rzeczywistości społecznej matryc wyobrażeń, postaw i działan, przejmowanych przez komunizm, zazwyczaj niejawnie, choć nader często intencjonalnie, zapewnia zabiegom propagandowym perswazyjną skuteczność. W zjawisku tym na swój sposób dochodzi do głosu również opisany przez Mirceę Eliadego mechanizm wykorzystywania przez komunizm ,prowincjonalizmów mitologicznych" - zastąpienia racjonalnego dyskursu politycznego mitem o charakterze pierwotnym, archaicznym, uniwersalizującym lokalną, partykularną opowieść danej społeczności (Eliade 1990: 255).

W okresie powojennym zsakralizowana sylwetka Tity jako herosa podlega znaczącym przeobrażeniom, m.in. poddana zostaje zabiegom deifikacji, która stanowi zasadniczy element założonego przez aparat propagandy programu mitologicznego. Jego osią jest dialektyczna relacja pomiędzy tym, co boskie, a tym, co ludzkie w publicznym wizerunku Marszałka. Z jednej strony zostaje on ubóstwiony, z drugiej boskość ta jest w różny sposób konfrontowana ze sferą indywidualna, prywatną, a nawet osobistą życia Tity - identyfikowaną jako element ludzki. Ta wpisana w strategie wizerunkowe dychotomia przywodzi na myśl (bliski mieszkańcom Jugosławii) model biblijny wraz z kluczowym podziałem na Stary i Nowy Testament oraz rozróżnieniem dwóch typów boskości, reprezentowanych odpowiednio przez starotestamentowego Jahwe oraz ewangelicznego bohatera - Boga-Człowieka.

W przypadku kultu Josipa Broza Tity, podlegającego w okresie powojennym intensywnym zabiegom instytucjonalizacji i dogmatyzacji, możemy dostrzec, że ewoluuje on wraz ze stanowiącym jego kontekst modelem rządów. Konstytucja symboliczna autorytetu jugosłowiańskiego przywódcy oraz wtłoczony w ramy komunistycznej ideologii publiczny scenariusz, będący formą reprezentacji sprawowanej przez Marszałka władzy, zmieniały się w zależności od aktualnej racji politycznej. Stąd też jego obraz jako wyniosłego, gniewnego, karzącego acz sprawiedliwego twórcy i wszechwładcy, w którym odnajdujemy rysy bóstw naczelnych typu pierwotnego, z czasem podlegać będzie znaczącym zabiegom antropomorfizacji. Strategia ta, oparta na ekspresji potocznych konstrukcji imaginacyj- 
nych, stanowi reakcję na określone przemiany społeczne i cywilizacyjne, po heroicznym okresie odbudowy państwa i uregulowaniu stosunków międzynarodowych, związane choćby z poczuciem unormowania się rzeczywistości społecznej oraz stabilizacją życia codziennego.

Okres wojny oraz powojennych rozrachunków z przeciwnikami ideologicznymi wpisany został mocą partyjnej propagandy w typowa, mityzującą ten czas narrację opartą na manicheistycznym schemacie. Ticie przypisano w niej rolę przywódcy sił dobra, który na drodze rewolucji, z pomocą partyzanckich oddziałów, wyprowadza świat z chaosu i ustanawia porządek oparty na nowych - także w aspekcie moralnym - zasadach, dowodząc przy tym swego nadnaturalnego potencjału. Ilustracją tej wizji, ujmującej działanie Tity, jego rewolucyjny czyn i wojskowe przywództwo w perspektywie odwiecznej walki dobra ze złem, w wymiarze wartości symbolicznych, mogą tu być słowa Envera Đerćeku: „On je spram Lucifera stao i bes je njegov srušio" - zapisane w poświęconym Brozowi wierszu Živ belutak. W podobnym uniwersalizującym kontekście ujmowane jest zainicjowane przez Broza dzieło tworzenia. Ranko Risojević w panegirycznym uniesieniu mówi o Ticie: „tvorac vremena i preporoditelj Smisla” (Andrić, Ršumović (red.) 1981: 26, 94) - utożsamia w ten sposób dźwignięcie $\mathrm{z}$ ruin Jugosławii z powołaniem do życia na nowo całego świata, nadaje temu aktowi kosmiczny wymiar, a także dokonuje transcendencji samej postaci demiurga, jego czyny bowiem przekraczają horyzont doświadczalnej, doraźnej rzeczywistości, a ich znaczenia nie można zredukować do wartości wyłącznie historycznych.

W budujących mitologię jugosłowiańską tekstach zwycięstwa militarne, a zwłaszcza czyn wyzwolenia ziem jugosłowiańskich, uzasadniano geniuszem wodza oraz bohaterską postawą żołnierzy, której źródłem była jego osobista charyzma. Milovan Đilas, odnosząc się sceptycznie do wojskowych talentów Tity oraz dystansując się wobec jego wizerunkowych uzurpacji, nazwał otoczoną legendą bitwę nad Sutjeską triumfem rewolucyjnej woli nad nowoczesną techniką wojskową, sukcesem umiejętnie spożytkowanym przez Titę dla realizacji własnych planów politycznych (Đilas 1980: 14). Niezależnie od tego, czy mamy do czynienia z interpretacją mityzująca, czy też z wyjaśnieniem racjonalizującym, nie ulega wątpliwości, że czas wojny okazał się przełomowym momentem zarówno w dziejach narodów południowosłowiańskich, jak i w życiorysie samego 
Josipa Broza. Jugosłowiańska mitologia wchłonęła wojnę i przypisała jej moc aktu kosmogonii. Wojna stała się osnową mitu założycielskiego komunistycznego państwa, zaprojektowanego jako ucieleśnienie nowego wspaniałego świata. Jego narodziny zostały ostatecznie przypieczętowane przez wydarzenia z 1948 roku, w których Tito odegrał wobec Józefa Stalina rolę iście prometejską. Wprawdzie w konsekwencji tego wydarzenia Jugosławia skazana została początkowo na polityczne wykluczenie z bloku państw komunistycznych i dotkliwą izolację ekonomiczna, niemniej Broz, odcinając się od modelu stalinowskiego i odrzucając tym samym status sowieckiego wasala, ustabilizował swoją przywódczą pozycję we władzach centralnych Federacji.

Parafrazując myśl Rogera Caillois, możemy powiedzieć, że wojna widziana w okresie po jej zakończeniu, w perspektywie wyzwolenia i odbudowy kraju, a ponadto jako czas wyłonienia się i praktycznej realizacji idei braterstwa oraz jedności, uznawana była nie tyle za dopust Boży, absurd czy też zło konieczne, które pozwalają narodom uniknąc zagłady, ile za „rację bytu narodowego bądź też jako czynnik określający naród: naród to ludzie, którzy walczą po tej samej stronie; wojna zaś to najwyższy wyraz narodowej woli istnienia" (Caillois 1995: 197). W tym ujęciu staje się ona początkiem, aktem odrodzenia, czasem regeneracji Kosmosu, a także aktem ideologicznej inicjacji. W mitycznie ukierunkowanym przekazie pole walki to obszar ścierania się sił kosmicznych, a tym samym miejsce szczególnego działania sacrum. Usankcjonowana mitem , liturgia wojny”przywodząca na myśl świąteczne zawieszenie rutyny dnia codziennego, erupcję sił i instynktów - potrzebuje właściwego sobie bóstwa. Wojna, co podkreśla Caillois, umożliwia epifanię boskości, dzięki której dokonuje się konsekracja wspólnoty (Caillois 1995: 198). Będąc sytuacją graniczną ujawnia to, co w człowieku nie-ludzkie, a co łatwo może zostać zidentyfikowane jako nadludzkie; w tym sensie często staje się progiem deifikacji (ale i demonizacji) jednostki.

W mitycznej wizji walki partyzanckiej Tito zyskuje rysy gniewnego choć sprawiedliwego bóstwa - nie waha się karać dotkliwie tych, którzy okazali się wrogami, tych, którzy mu się sprzeciwili, tych, którzy zdradzili sprawę. Logika wojny i walki ideologicznej bez trudu znajduje uzasadnienie dla egzekucji, więzień i potępienia. Caillois przypomina, że wojna 
jest szczególnym czasem wzburzenia i przemiany ${ }^{4}$, który podobnie jak święto wymaga składania ofiar, ponieważ od nich zależy regeneracja sił wspólnoty.

Obok tekstów ludowych, anonimowych, jak i „uczonych”, autorskich, które składają się na bogaty repertuar twórczości titoistycznej, symbolicznemu wytwarzaniu autorytetu Marszałka służyły wszelkiego rodzaju ceremonie państwowe i publiczne obrzędy - takie jak choćby najbardziej spektakularne, imponujące gigantyzmem quasi-sportowej choreografii, centralne obchody Dnia Młodości organizowane rokrocznie 25 maja na stadionie Jugosłowiańskiej Armii Ludowej w Belgradzie. To proklamowane przez Broza w miejsce własnych urodzin ogólnopaństwowe święto, z rytuałem sztafety jako kulminacyjnym punktem uroczystości, dobrze wpisywało się w mit początków poprzez afirmację młodości, witalizmu, nowego ładu. Jednocześnie w ramach Dnia Młodości dokonywało się kluczowe utożsamienie (biografii) Tity i państwa - sprzyjające deifikacji osoby przywódcy. Rozbudowany i różnorodny spektakl władzy, w którym Tito wobec wiwatujących tłumów łatwo wcielał się w rolę deus otiosus, był najskuteczniejszym sposobem osiagania efektu numinosum, opartego podobnie jak w klasycznej koncepcji Rudolfa Otto - na manifestacji wszechmocy, wzniosłości, wielkości oraz na odczuciu fascynacji, strachu i całkowitej zależności (Otto 1999).

Formami epifanicznej obecności Tity (stanowiącej zarazem formę kontroli symbolicznej) w codziennym życiu obywateli Federacji było słowo: odezwy, przemówienia, hasła emitowane przez radio oraz powielane w prasie, książkach i innego rodzaju drukach, a także podobizny plastyczne: popiersia wystawiane masowo w miejscach publicznych, portrety rozwieszane w urzędach i szkołach, niesione w pochodach oraz eksponowane w przestrzeni prywatnej - w domach; ważną kultotwórczą funkcję spełniał film, zwłaszcza dzieła sławiące zryw partyzancki.

Warto w tym miejscu przypomnieć prześmiewcze, a jednocześnie wyjątkowo trafne $w$ diagnozie sytuacji nawiązanie do propagandowego wyobrażenia Tity jako demiurga, powstałe już po jego śmierci i po rozpa-

\footnotetext{
${ }^{4}$ Ważną rolę w ugruntowaniu kultu Tity odegrała m.in. wydana w 1953 roku, zawierająca obszerne materiały biograficzne praca Josip Broz. Tito. Prilozi za biografiju pióra Vladimira Dedijera, jednego z czołowych animatorów jugosłowiańskiego aparatu propagandy, uznanego za oficjalnego biografa Josipa Broza.
} 
dzie socjalistycznej Jugosławii. Dejan Novačić w po części kpiarskiej, po części nostalgicznej, popularnej broszurze SFRJ za ponavljače. Turistički vodič przedstawia „ludową legendę” o powstaniu Jugosławii, stylizując narrację na wzór Księgi Genesis:

1. U početku bijaše zemlja bez obličija i bijaše tama nad bezdanom. I reče Tito: neka bude svjetlost. I bi svjetlost.

2. I odvoji Tito svjetlost od tame i nazva Tito svjetlost naši, a tamu nazva njihovi.

3. I opet reče Tito: neka bude zvijezda petokraka. I bi tako. I postavi je Tito na svod nebeski da obasjava zemlju sjajem nebeskim.

(...). I vidje Tito da je to dobro (Novačić 2002: 5).

Autor poprzez trawestację świętej opowieści przewrotnie ukazuje działanie strategii ubóstwienia panującego polegającej na przypisaniu mu „cudu” stworzenia, co stanowi w istocie rzeczy irracjonalne i niejako mechaniczne usankcjonowanie jego władczych prerogatyw, ale za to czyni zeń obiekt kultu wyznawanego przez masy.

Upowszechnienie wśród narodów Jugosławii ideologii komunistycznej i kultu Josipa Broza prowadziło do różnych przejawów pauperyzacji wyobrażeń o nim. Wizerunek ubóstwionego Tity poddany został przede wszystkim zabiegom antropomorfizacji, która - jak już wspominałam - jest przejawem dialektycznej gry między tym, co ludzkie, a tym, co Boskie. W ujęciu Rudolfa Otto przeżycie numinotyczne zakłada istnienie nieprzekraczalnego dystansu, absolutyzację wartości symbolicznych, separację od tego, co jednostkowe, anegdotyczne, czasowe, przygodne na rzecz odczucia w akcie mysterium tremendum jakości wiecznych (Otto 1999: 95). W rzeczywistości dyskursywnej, która uruchamia aparat racjonalizacji, ale przede wszystkim w potocznej percepcji świętości myśl ludzka dokonuje swoistego przekładu sacrum w kluczu swojskości i sensualizmu.

Tego rodzaju przedstawień jugosłowiańskiego przywódcy, operujących prostym konkretem, redukujących dystans i lokujących jego postać w sferze codzienności, wymagał m.in. przekaz szkolny, stąd też podręczniki i inne publikacje dla dzieci często przywoływały sceny z dzieciństwa małego Jožy. Opowiadania o dzieciństwie wodza przybierały charakter pouczających i umoralniających egzemplów, które w projekcie wychowania spełniały doniosłą funkcję adaptacyjną - pozwalały usytuować dziecięcy świat w obowiązującym porządku ideologicznym. 
Quasi-hagiograficzne przedstawienia życiowej drogi Josipa Broza domagały się odpowiednich reprezentacji przestrzennych, dowodnie ukazujących, że oto sacrum, jakby powiedział Eliade, zostało zakonspirowane w zwykłości. Prawdziwym sanktuarium, stanowiącym w okresie socjalizmu obowiązkowy cel szkolnych i zakładowych wycieczek, a także peregrynacji kolektywów partyjnych, stał się Kumrovec - chorwacka wieś określana dziś ironicznie mianem jugosocjalistycznego Betlejem, w którym w ubogiej rodzinie Brozów wydane zostało na świat przez Titorodzicę (Mariję Broz) Ticiątko mające $\mathrm{w}$ przyszłości objawić się jako obrońca uciśnionych klas społecznych i wyzwoliciel narodów Jugosławii (Prodanović 2011: 86). Dla porządku należy przypomnieć, że w 1946 roku z powodów ideologicznych dokonano dość szczególnej przebudowy gospodarstwa rodziny Brozów, aby uwiarygodnić biograficzny kanon. Zburzono stary dom i wybudowano nowy skromniejszy, ale za to znacznie bardziej odpowiadający forsowanej przez propagandę wizji bohatera: dzielnego chłopca - syna ziemi chłopów i robotników, który od najmłodszych lat wiódł wraz z licznym rodzeństwem życie w najgłębszej nędzy, dzięki czemu na własnej skórze doświadczył nierówności klasowych (Krstić 2006: 19). Z upływem lat mały, „błotnisty” Kumrovec przemienił się w okazałe centrum politycznego kultu - nie tylko wybudowano tu w 1956 roku szkołę podstawową pod patronatem wybitnego kumrowczanina, lecz także otwarto w 1974 roku hotel i ośrodek konferencyjny, a przede wszystkim Dom Bojowników i Młodzieży (Dom boraca i omladine), gdzie rozpoczęła działalność rekrutująca kadry partyjne Szkoła Polityczna. Przede wszystkim jednak $\mathrm{w}$ ramach programu instytucjonalizacji rodzinnej wsi Tity jako kluczowego obiektu na polityczno-turystycznej mapie Jugosławii (a w intencjach organizatorów, jak można sądzić na podstawie dostępnej dokumentacji, także świata) powołano do życia profesjonalne historyczno-etnologiczne muzeum. Architekci tego pomysłu zadbali o wyeksponowanie znaków niegdysiejszej obecności mieszkańców miejsca (włącznie z krzyżem i oleografiami przedstawiającymi sceny z Pisma Świętego). Przy rekonstrukcji ,autentycznych” wnętrz częściowo zastąpiono stare przedmioty nowymi, specjalnie do tego celu skupowanymi w Słowenii. Szczególnie zadbano o nadanie obejściu rustykalnego stylu, tak, by przypominało typowe dla regionu gospodarstwa z przełomu XIX i XX wieku (Krstić 2006). Urządzony w ten sposób skansen miał funkcjonować nie 
tylko jako przestrzeń wystawiennicza, ale także odpowiednia sceneria okolicznościowych wydarzeń, uroczystości poświęconych Marszałkowi. Ostatecznie obiekt stał się miejscem, w którym, wzorem potiomkinowskich wsi, odgrywano socjalistyczną idyllę.

Nakreślona powyżej strategia antropomorfizacji publicznego wizerunku Tity nie polega więc na porzuceniu zabiegów sakralizacji i deifikacji, ujawnia jedynie ich dodatkowe modalności. Pozwala wpisać osobę jugosłowiańskiego przywódcy w nowy paradygmat, który zapewnia skuteczność politycznemu rytuałowi podtrzymywania władzy. O wyraźnie czytelnych analogiach nowotestamentowych można tu mówić nie tylko w odniesieniu do „ewangelii dzieciństwa” Josipa Broza, ponieważ, jak się wydaje, najbardziej znacząca paralela związana jest połączeniem idei wcielenia jako rodzaju teofanii z motywem misji - misji zbawiciela. Ta symboliczna syntagma ujawnia się także w wizerunkowych konstrukcjach postaci Tity, albowiem właśnie w kategoriach misji - uniwersalnego posłannictwa pokoju dla świata pogrążonego w zimnej wojnie - ukazywana była w jugosłowiańskim dyskursie propagandowym międzynarodowa działalność Tity jako lidera Ruchu Państw Niezaangażowanych. Jednocześnie figura zbawcy zwaśnionego świata pozwalała na tyle wzbogacić kapitał symboliczny (określenie Pierre'a Bourdieu), by można było odnaleźć dogodny tryb retoryczny dla przedstawiania dostojnie starzejącego się władcy i wpisać w moralny panteon ludzkości, tym bardziej że z upływem czasu ściśle ideologiczna esencja kultu uległa zwietrzeniu, należało go więc zasilić aktualną treścią.

Komunistyczny kult jednostki, z uwagi na swój religiopodobny charakter, jest zazwyczaj traktowany jako efekt uboczny zastosowania w politycznej praktyce marksistowskiej doktryny materializmu - reakcja na wyrugowanie religii z porządku społecznego, jego zadekretowaną świeckość, a także programową laicyzację życia obywateli zarówno w sferze publicznej, instytucjonalnej, jak i prywatnej. Omówiony powyżej przykład sakralizacji i deifikacji osoby Josipa Broza dowodzi, że mechanizmowi wypełnienia próżni, która powstaje w wyniku zabiegów redukcji rzeczywistości do wymiaru horyzontalnego, sprzyja utrwalona w tradycji i mentalności mieszkańców danego obszaru geograficzno-kulturowego percepcja władzy w kategoriach religijnych z właściwymi jej sposobami ekspresji, za sprawą których adoracja przywódcy często przyobleka się w formy ludowego 
kultu religijnego, stając się, co podkreśla Leszek Kołakowski, w istocie rzeczy zniekształceniem czy wręcz parodią religii (Kołakowski 1976: 153). Boskość nie jest tu funkcją teologicznie zdefiniowanej transcendencji, lecz projekcją oczekiwań społecznych, lokowanych w osobie przywódcy. Ewokowana w postaci rytuałów, ceremonii, wszelkich symbolicznych praktyk, przynosi tak potrzebne zagospodarowanie zbiorowych emocji i pokładów tego, co nie pozwala łatwo się wtłoczyć w ramy racjonalnej postawy wobec rzeczywistości (Tito dość łatwo przyobleka maskę duchowego przywódcy narodu - najpierw w imię komunistycznych, a następnie uniwersalnie pojętych humanistycznych ideałów). Do tych mechanizmów wywyższenia odwołuje się poświęcona i dedykowana władcy twórczość artystyczna, w której zabiegi ubóstwienia stanowią typowy chwyt panegiryzmu, estetyzują pochlebstwo, legitymizuja, a tym samym wpisują się w działania propagandy.

Rozważany tu przypadek jugosłowiański zwraca także uwagę na dodatkowy aspekt atrybutu boskości, w jaki wyposażana jest władza komunistycznego przywódcy. Jeśli spojrzymy na fenomen sakralizacji osoby i czynów Josipa Broza nie tylko przez pryzmat religijnych zapożyczeń, analogii i deformacji, lecz także w kontekście specyfiki lokalnej kultury politycznej, to - mimo deklarowanego definitywnego zerwania drugiej Jugosławii z przeszłością - dostrzeżemy ciagłość pewnych form, zwłaszcza w sferze publicznego funkcjonowania władzy państwowej, przede wszystkim w odniesieniu do Królestwa Jugosławii z okresu międzywojennego, w jej lokalnych europejskich umotywowaniach. Przyjmując nieuniknione ryzyko uproszczenia, można stwierdzić, że choć w obu przypadkach dyktatura opiera się na innym systemie rządów oraz legitymizuje odmienny porządek ideologiczny, dyktaturą być nie przestaje. System komunistyczny wprowadzany planowo w życie powojennej Jugosławii z powodzeniem wykorzystuje i afirmuje - zakorzeniony w tradycjach monarchicznych, jakie w toku historii stały się udziałem zamieszkujących region narodów paternalistyczny model władzy, którego doskonałą realizację przynoszą rządy Josipa Broza. Petryfikują one stan swoistej niedojrzałości politycznej jugosłowiańskiej wspólnoty, opierając proces formowania się podmiotowości obywatelskiej na zależności od niepodważalnego autorytetu przywódcy. A przecież kult w obawie przed zakwestionowaniem czy relatywizacją tabuizuje to, co powinno być przedmiotem refleksji i krytyki. 
W przypadku Jugosławii po drugiej wojnie światowej na dość wątłe doświadczenie państwa nowoczesnego typu nakłada się karkołomna próba stworzenia ponadnarodowej wspólnoty, która oprócz scentralizowanych instytucji państwowych potrzebuje czytelnych znaków jedności. Tę funkcję, obok idei braterstwa narodów, spełnia doskonale jej patron - niepokonany, wszechmocny, nieśmiertelny „bóg” Titosłowian.

\section{Literatura}

Andrić R., Ršumović Lj., red., 1981, Tito o piscima, pisci o Titu, Beograd.

Caillois R., 1995, Wojna i sacrum, w: R. Caillois, Człowiek i sacrum, przeł. A. Tatarkiewicz, E. Burska, Warszawa, s. 187-206.

Ćalović D., 2006, Josip Broz Tito - studija imidža, Beograd.

Đilas M., 1980, Druženje s Titom, Harrow.

Eliade M., 1990, Religia, literatura, komunizm. Dziennik emigranta, przeł. A. Zagajewski, Warszawa.

Kołakowski L., 1976, Główne nurty marksizmu, t. 2, Paryż.

Kornhauser J., 2001, Wiersze o Ticie. Ludowy stereotyp socrealistyczny, w: J. Kornhauser, Świadomość regionalna i mit odrębności (o stereotypach w literaturze serbskiej i chorwackiej), Kraków, s. 69-81.

Krstić K., 2006, Tišina koja govori. Iz dokumentacije Marijane Gušić, osnivačice Muzeja u Titovom Kumrovcu, w: O Titu kao mitu. Proslava Dana mladosti u Kumrovcu, red. N. Škrbić Alempijević, K. Mathiesen Hjemdahl, Zagreb, s. 97-119.

Kula M., 2003, Religiopodobny komunizm, Kraków.

Luckmann T., 2006, Niewidzialna religia. Problem religii we wspótczesnym spoteczeństwie, Kraków.

Марковић П.Ј., 2012, Тито и његово доба, w: П.Ј. Марковић, В. Кецмановић, Тито - поговор, Београд.

Николић К., 2006, Тито говори што народ мисли. Култ Јосипа Броза 1944-1949, Београд.

Novačić D., 2002, SFRJ za ponavljače. Turistički vodič, Beograd.

Otto R., 1999, Świętość. Elementy irracjonalne w pojęciu bóstwa i ich stosunek do elementów racjonalnych, przeł. B. Kupis, Warszawa.

Prodanović M., 2011, Titina majka, w: M. Prodanović, Tranziciona galanterija, Zrenjanin, s. 81-87. 